\title{
An Acid Protease Produced by Monilinia fructigena in vitro and in Infected Apple Fruits, and its Possible Role in Pathogenesis
}

\author{
By E. C. HISLOP, ${ }^{1 *}$ JAN L. PAVER $^{2}$ AND J. P. R. KEON ${ }^{1}$ \\ ${ }^{1}$ Long Ashton Research Station, University of Bristol, Long Ashton, Bristol BS18 9AF, U.K. \\ ${ }^{2}$ Wye College, Nr. Ashford, Kent TN25 5AH, U.K.
}

(Received 1 June 1981; revised 8 August 1981)

\begin{abstract}
The fungus Monilinia fructigena grown in a liquid medium containing protein secreted a protease with many similarities to one extractable from apple fruits infected with this pathogen but absent from healthy fruit. Enzymes from both sources degraded several protein substrates optimally at $\mathrm{pH} \mathrm{3.4}$. At this $\mathrm{pH}$, haemoglobin was degraded optimally at $47{ }^{\circ} \mathrm{C}$, while at $37^{\circ} \mathrm{C}$ both enzymes were most stable at $\mathrm{pH}$ 5. The pI values for the enzymes were close to $4 \cdot 0$, and their action was inhibited by pepstatin and diazoacetyl-norleucine methyl ester plus copper ions but unaffected by $p$-hydroxymercuribenzoate, EDTA or trypsin inhibitors. Mercaptoethanol was essential for the recovery of enzyme activity from acrylamide gels in which the in vitro and in vivo enzymes were electrophoretically homogeneous. The in vitro enzyme gave a positive reaction for glycoproteins after purification with a Sepharose-haemoglobin affinity medium. Both enzymes were single units with a molecular weight of $37000-40000$ on sodium dodecyl sulphate (SDS)-polyacrylamide gels; gel filtration indicated a molecular weight of 34000-38000. The purified in vitro enzyme had no aminopeptidase or carboxypeptidase activity; the products of haemoglobin digestion were peptides with molecular weights on SDS-polyacrylamide gels of 2000-12000. Purified in vitro protease did not damage apple fruit tissue or cultured apple cells, lyse plant protoplasts or release proteins from isolated fruit cell walls. The protease had no effect on active fungal or host enzymes that might have a role in host/pathogen interactions, and did not induce phaseollin formation in bean cotyledons. The plant proteins vicilin, legumin and heat-denatured peroxidase were hydrolysed at $\mathrm{pH} 3.5$ and spinach nitrate reductase was inactivated. No natural protease inhibitors were detected in healthy or infected apples. We suggest that in vivo the protease might be involved in the nutrition of the pathogen.
\end{abstract}

\section{INTRODUCTION}

Although a considerable number of fungi from widely different taxonomic classes have long been known to produce extracellular proteolytic enzymes, their possible role in host plant and fungal pathogen interactions has been very largely ignored (Bateman \& Basham, 1976). There are apparently no detailed studies confirming that proteases secreted by pathogens grown in vitro also occur in plant tissues infected by them, and only in two instances have some data indicated this possibility (Khare \& Bompeix, 1976; Urbanek \& Yirdaw, 1978). This is in contrast to numerous data on the occurrence and roles in pathogenesis of fungal pectolytic enzymes (e.g. Bateman \& Basham, 1976; Mussell \& Strand, 1977; Wood, 1978; Byrde, 1979). Thus, we examined the possibility that a protease known to be present in apple fruit tissues infected with Monilinia fructigena but absent from healthy fruit (Hislop et al., 1973) was produced by the pathogen rather than by the host, and that it might have a role in pathogenesis. It is important to examine these aspects so that 
considerations relating to the possible interplay of natural host inhibitors and extracellular fungal proteases, frequently alluded to as being important in host/pathogen interactions (e.g. Mosolov et al., 1979), can be validated.

\section{METHODS}

Conidia of Monilinia fructigena (Aderh. \& Ruhl.) Honey (ATCC 26106) were produced on V8 juice agar (Byrde \& Fielding, 1968) and added to liquid culture media in conical flasks to give approximately 2-3 $\times 10^{3}$ spores $\mathrm{ml}^{-1}$. Cultures were maintained in the dark at $25^{\circ} \mathrm{C}$; they were kept static for $24 \mathrm{~h}$ and then agitated at 150 oscillations $\mathrm{min}^{-1}$ for up to a further $7 \mathrm{~d}$. Of a number of culture media examined the following mixture gave good protease activity within $4 \mathrm{~d}$ of inoculation: soya peptone (Oxoid), $20 \mathrm{~g}$; glucose, $10 \mathrm{~g} ; \mathrm{MgSO}_{4} \cdot 7 \mathrm{H}_{2} \mathrm{O}, 0.1 \mathrm{~g}$; $\mathrm{KNO}_{3}, 2.5 \mathrm{~g}$; distilled water, 11 . The $\mathrm{pH}$ of the medium after autoclaving was 5.5 .

Golden Delicious or Cox's Orange Pippin apples were inoculated with $M$. fructigena and incubated at $25^{\circ} \mathrm{C}$ for 4-5 d. Infected tissue, and healthy tissue from uninoculated fruit, was sliced, ground with fine acid-washed sand, and extracted with Mcllvaine's buffer pH 5.3 containing $0.06 \mathrm{M}$-sodium thioglycollate and $0.1 \%(\mathrm{w} / \mathrm{v})$ Triton $\mathrm{X}-100$ ( $1 \mathrm{~g}$ tissue to $2 \mathrm{ml}$ solution). The supernatant after centrifugation at $4{ }^{\circ} \mathrm{C}(18000 \mathrm{~g})$ was dialysed against cold $0.06 \mathrm{M}$-sodium thioglycollate.

Routine protease assays were performed by a spectrophotometric technique (Anson, 1938) with $1 \%(\mathrm{w} / \mathrm{v})$ denatured haemoglobin (Sigma, type II) in McIlvaine's buffer pH 3.5. The reaction mixture, containing $4 \mathrm{ml}$ substrate and up to $0.5 \mathrm{ml}$ enzyme solution, was incubated at $37^{\circ} \mathrm{C}$ for times that were kinetically valid. Reactions were terminated by the addition of $3 \mathrm{ml} 5 \%(\mathrm{w} / \mathrm{v})$ trichloroacetic acid (TCA), and acid-soluble products in the supernatant were measured by reading the absorbance at $280 \mathrm{~nm}$. Zero-time blanks and controls lacking substrate were also included. One unit of enzyme activity was arbitrarily defined as the change in absorbance at $280 \mathrm{~nm}$ produced by $1 \mathrm{ml}$ enzyme solution after incubation for $1 \mathrm{~h}$ at $37^{\circ} \mathrm{C}$. Occasionally, tryosine equivalents were measured using the Folin phenol reagent (Anson, 1938) or L-leucine equivalents were determined with ninhydrin (Yemm \& Cocking, 1955).

A cup plate assay technique for estimating protease activity was also used; the medium was $2 \%(\mathrm{w} / \mathrm{v})$ agar and $1 \%(\mathrm{w} / \mathrm{v})$ gelatine, buffered as required. The enzyme solution, in $6 \mathrm{~mm}$ diameter wells, was incubated overnight at $25^{\circ} \mathrm{C}$ and the plate was developed with $15 \%(\mathrm{w} / \mathrm{v})$ mercuric chloride in $20 \% \mathrm{HCl}[20 \mathrm{ml}$ conc. $\mathrm{HCl}$ (sp.gr. $1 \cdot 18$ ) plus $80 \mathrm{ml}$ distilled water].

An alternative assay system was similar to that of Rinderknecht et al. (1968) using hide powder azure (Sigma); the release of soluble dye was measured at $595 \mathrm{~nm}$. Carboxypeptidase and aminopeptidase activity were measured by the methods of Nakadi et al. $(1972,1973)$.

Filtrates from liquid cultures and extracts of healthy and infected apple tissue were commonly concentrated by ammonium sulphate precipitation; the precipitate forming at $90 \%$ saturation was retained for further use. The precipitates were typically dissolved in $0.025 \mathrm{M}$-sodium acetate buffer $\mathrm{pH} 4.1$ and extensively dialysed against the same buffer at $4{ }^{\circ} \mathrm{C}$. These preparations were usually further purified by affinity chromatography, isoelectric focusing and/or gel filtration.

The affinity medium was a conjugate of haemoglobin (Sigma, type I) and cyanogen bromide-activated Sepharose 4B (Pharmacia), as first described by Chua \& Bushuk (1969) and employed by Drivdahl \& Thimann (1977). The enzyme sample (80-100 mg protein) was added to the affinity medium in a small glass column and washed with $0.025 \mathrm{M}$-sodium acetate buffer $\mathrm{pH} 4.1$ at $20-30 \mathrm{ml} \mathrm{h}^{-1}$. Bound proteins were eluted with $0.1 \mathrm{M}$-acetic acid $\mathrm{pH} 3 \cdot 1$, and fractions were quickly adjusted to $\mathrm{pH} 5$ with $4 \mathrm{M}$-sodium acetate.

Protease samples dialysed against distilled water were also purified by wide-range $(\mathrm{pH} 3-10)$ and narrow-range (pH 3-6) isoelectric focusing according to the general method of Vesterberg \& Svensson (1966) using a $110 \mathrm{ml}$ LKB column. Purification and molecular weight measurement was also done by exclusion chromatography on a Sephadex G-100 column $(67 \times 3 \mathrm{~cm})$ according to the method of Andrews (1964) with bovine serum albumin (Sigma, Fraction V), ovalbumin (Sigma, type VII), $\beta$-lactoglobulin (Sigma, L 7880), $\alpha$-chymotrypsinogen A (Sigma, type II) and cytochrome $c$ (Sigma, type II from beef heart) as standards.

Polyacrylamide disc gel electrophoresis in a continuous buffer system (Hjerten et al., 1965) was performed with $0.05 \mathrm{M}$-sodium acetate buffer $\mathrm{pH} 5.5$ containing $4.8 \mathrm{~mm}$-mercaptoethanol and $7.5 \%(\mathrm{w} / \mathrm{v})$ acrylamide. Proteins in the gels were either stained with Coomassie blue G250 (0.04\%) in $3.5 \%(\mathrm{v} / \mathrm{v})$ perchloric acid (Reisner et al., 1975) or sliced and extracted to recover enzyme activity. Sodium dodecyl sulphate (SDS)-polyacrylamide gel electrophoresis was done by the method of Shapiro et al. (1967) and of Weber \& Osborn (1969), using Combithek calibration proteins (Boehringer, cat. no. 15661). The products of haemoglobin digestion by purified protease were also examined on SDS-polyacrylamide gels by the method of Swank \& Munkres (1971) using BDH molecular weight marker kit no. 44247 2L (molecular weight range 2512-16949). Glycoproteins in gels were detected by the periodic acid-Schiff's reagent technique of Zacharius et al. (1969). 
Proteases from in vitro and in vivo sources were characterized by their response to a number of synthetic and natural inhibitors (e.g. Salmia et al., 1978; Tsai et al., 1978). Diazoacetyl-norleucine methyl ester (DAN, Sigma) inhibition was tested by the method of Rajagopalan et al. (1966). Natural inhibitors examined included pepstatin A (Aoyagi et al., 1971) and trypsin inhibitors from soybean and lima bean (all from Sigma). Spinach nitrate reductase was a gift from B. A. Notton, Long Ashton Research Station; all other enzymes examined for inactivation by the purified protease, other than pectic enzymes secreted by $M$. fructigena, were purchased from Sigma. The physiological effects of the protease on cultured apple cells were examined as described previously (Hislop et al., 1979).

Protein determinations were usually made by the dye-binding method (Bradford, 1976) in which the Bio-Rad reagents (Bio-Rad Laboratories; Technical Bulletin 1051, 1977) were used.

\section{RESULTS AND DISCUSSION}

Preliminary studies with liquid cultures confirmed that several proteins examined were capable of inducing secretion of a protease which was most active at an acid $\mathrm{pH}$. Fungal growth in the soya peptone medium was rapid so that cultures could be harvested within 3-4 d yielding reasonable protease activity. Such activity was absent from media containing pectin (e.g. Byrde \& Fielding, 1968) used as an inducer for pectolytic enzyme secretion. The specific activity of acid protease in crude culture filtrates was about 120 units (mg protein) ${ }^{-1}$ and this was approximately doubled in the $90 \%$ ammonium sulphate precipitate. In comparison, activities in the crude extract of infected apples and the $90 \%$ ammonium sulphate precipitate were about 25 and 100 units (mg protein $)^{-1}$, respectively. Affinity chromatography on the Sepharose-haemoglobin column resulted in an elution profile similar to that illustrated by Drivdahl \& Thimann (1977) and commonly produced at least a 10 -fold increase in specific activity, with recovery of between 60 and $70 \%$ of the applied activity in the two peak fractions $(5.5 \mathrm{ml}$ each). These purification procedures accounted for about $90 \%$ of the total protease activity of the crude culture filtrate. Gel filtration with Sephadex G-100 produced only a small increase in specific activity (up to 2 -fold). The most active fractions from gel filtration revealed only single protein bands after disc gel electrophoresis when the amounts of protein from the in vitro and in vivo preparations added to the gels were 100 and $16 \mu \mathrm{g}$, respectively (limit of detectability, about $10 \mu \mathrm{g}$ protein per band). Protease activity was readily recovered from these gels only if mercaptoethanol was included in them and in the running buffers. Maximum activity (measured as TCA-soluble haemoglobin digestion products) was recovered from areas of gel where the single protein band was thought to be in comparison with stained 'sister' gels. However, for both the in vitro and in vivo enzymes some activity was recovered from up to $1 \mathrm{~cm}$ on either side of the centre of the protein band (Fig. 1). Mercaptoethanol does not affect the hydrolysis of haemoglobin by the protease and it might be acting in gels to protect the enzyme from the oxygen-rich conditions and free radicals which occur when ammonium persulphate is used for polymerization.

The in vitro enzyme, but not that from infected apples where the protein concentration was probably too low, gave a strong positive reaction for polysaccharide as a single band when gels were treated with the periodic acid-Schiff's reagent. An analysis of the sugar components of one sample of the in vitro enzyme indicated $58 \mathrm{nmol}$ galactose and $37 \mathrm{nmol}$ glucose per $\mathrm{mg}$ protein, with smaller amounts of mannose, $\mathrm{N}$-acetylglucosamine and $\mathrm{N}$-acetylgalactosamine (J. R. Clamp, personal communication). Electrophoresis on SDS-polyacrylamide gels indicated that both enzymes were composed of only one unit with a molecular weight between 37000 and 40000. For comparison, gel filtration indicated a molecular weight of 34000-38000.

The $\mathrm{pH}$ optimum for the hydrolysis of haemoglobin and hide powder azure by the in vitro enzyme and of haemoglobin by the in vivo enzyme was close to 3.4 (Fig. 2) with significantly reduced activity above $\mathrm{pH} 5$. However, at $37^{\circ} \mathrm{C}$ the in vitro enzyme was most stable at about pH 5 with $50 \%$ loss of activity after $21 \mathrm{~h}$ incubation. At pH 3.5 the optimum temperature for haemoglobin hydrolysis was close to $46^{\circ} \mathrm{C}$, but the enzyme was virtually inactive above $55^{\circ} \mathrm{C}$. 


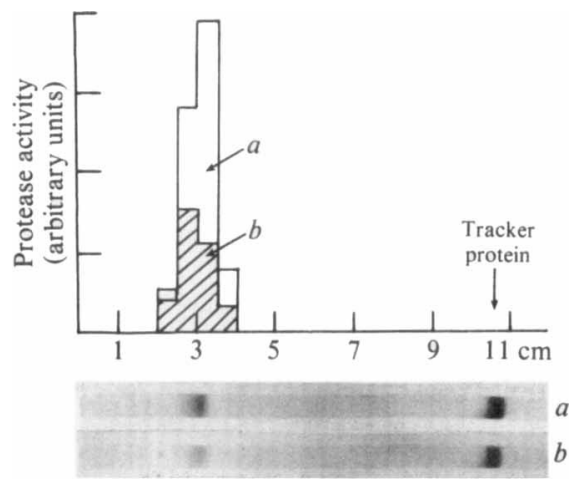

Fig. 1. Recovery of in vitro $(a)$ and in vivo $(b)$ proteases from polyacrylamide disc gels run in a 'continuous' sodium acetate buffer ( $\mathrm{pH} 5.5)$ system containing $4.8 \mathrm{mM}$-mercaptoethanol.
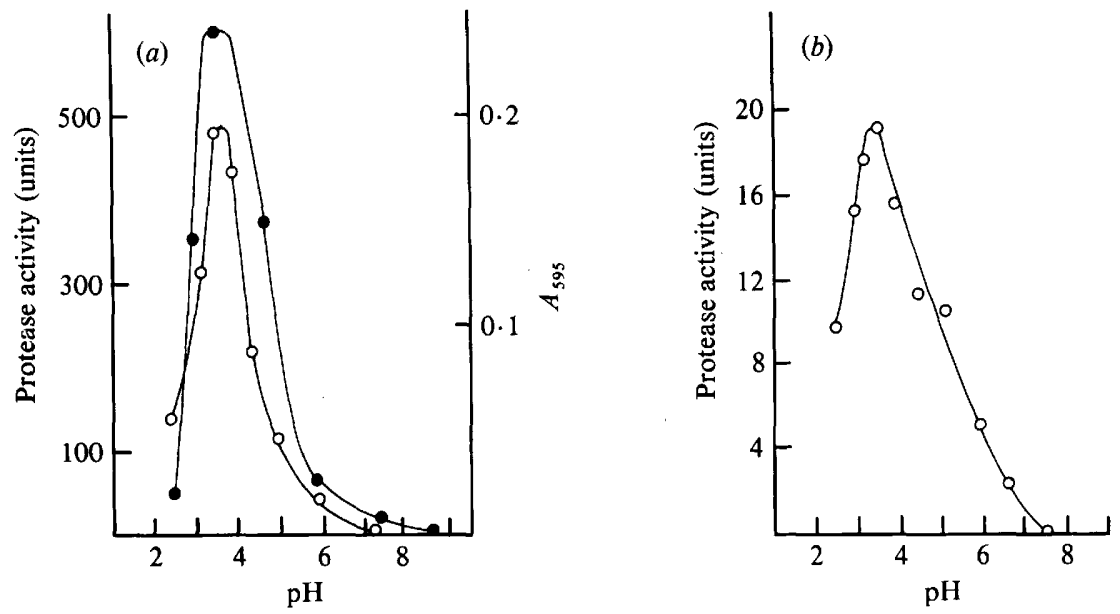

Fig. 2. Effect of $\mathrm{pH}$ on the digestion of haemoglobin $(O)$ and hide powder azure $(O)$ by the in vitro protease $(a)$ and of haemoglobin (O) by the in vivo enzyme $(b)$ using Mcllvaine's wide-range citric acid/sodium phosphate buffer.

Confirmatory evidence that the haemoglobin-degrading enzymes from both sources are typical acid proteases was provided by their inhibition by pepstatin A (Fig. 3) and DAN plus copper ions (Fig. 4). In the absence of copper ions, or when the reaction is carried out in buffer containing citrate ions (which chelate copper), DAN is non-inhibitory. The proteases were inhibited by SDS (1 mM) and $\mathrm{Fe}^{3+}(10 \mathrm{mM})$ but not by EDTA, p-hydroxymercuribenzoate or mersalyl acid. A final piece of evidence that the acid proteases produced in liquid culture and in infected apples are probably the same was the similarity in their isoelectric points, which were between 4.0 and $4 \cdot 2$.

Attempts were made to determine whether the acid protease produced in culture and in vivo had any properties which might affect host/pathogen interactions. The protease is an endoprotease producing haemoglobin digestion products with molecular weights of 2000-3000 after incubation for $32 \mathrm{~min}$ (Fig. 5). Progress curves for the hydrolysis of haemoglobin at the time intervals illustrated in Fig. 5, measured by four common techniques, are shown in Fig. 6. It is clear that while any of the methods used gives a good indication of the progress of hydrolysis a combination of one of these with gel electrophoresis is potentially more informative. 


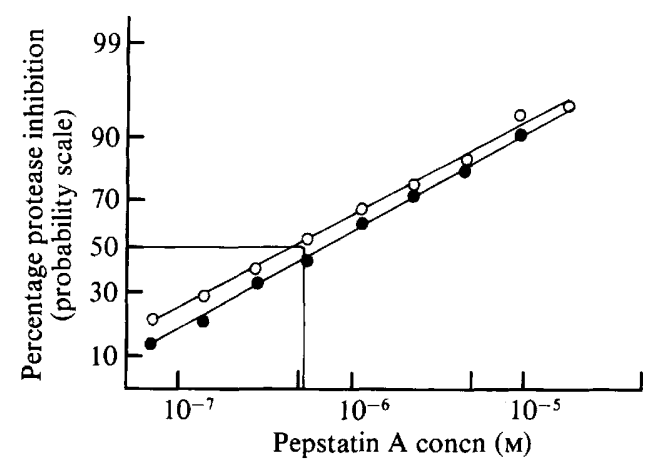

Fig. 3

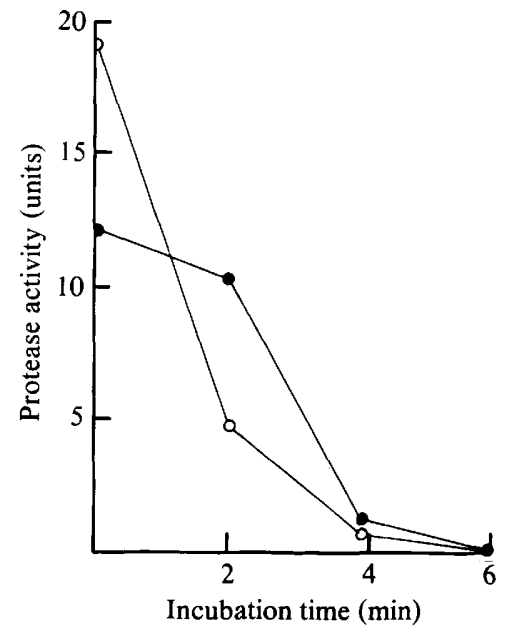

Fig. 4

Fig. 3. Inhibition of the in vitro (O) and in vivo (O) proteases by pepstatin $A$.

Fig. 4. Inhibition of the in vitro $(O)$ and in vivo $(O)$ proteases by diazoacetyl-norleucine methyl ester (DAN). The reaction mixture containing $0.5 \mathrm{ml}$ enzyme, $0.5 \mathrm{ml}$ sodium acetate buffer $(0.1 \mathrm{M}) \mathrm{pH} 5.2$ and $0.2 \mathrm{ml} 0.01 \mathrm{M}$-copper acetate was incubated for $10 \mathrm{~min}$ before $0.2 \mathrm{ml} \mathrm{DAN}$ in methanol $(26 \mathrm{mg}$ $\mathrm{ml}^{-1}$ ) was added (zero time). Controls lacking DAN or copper ions were unaffected during these incubation times.

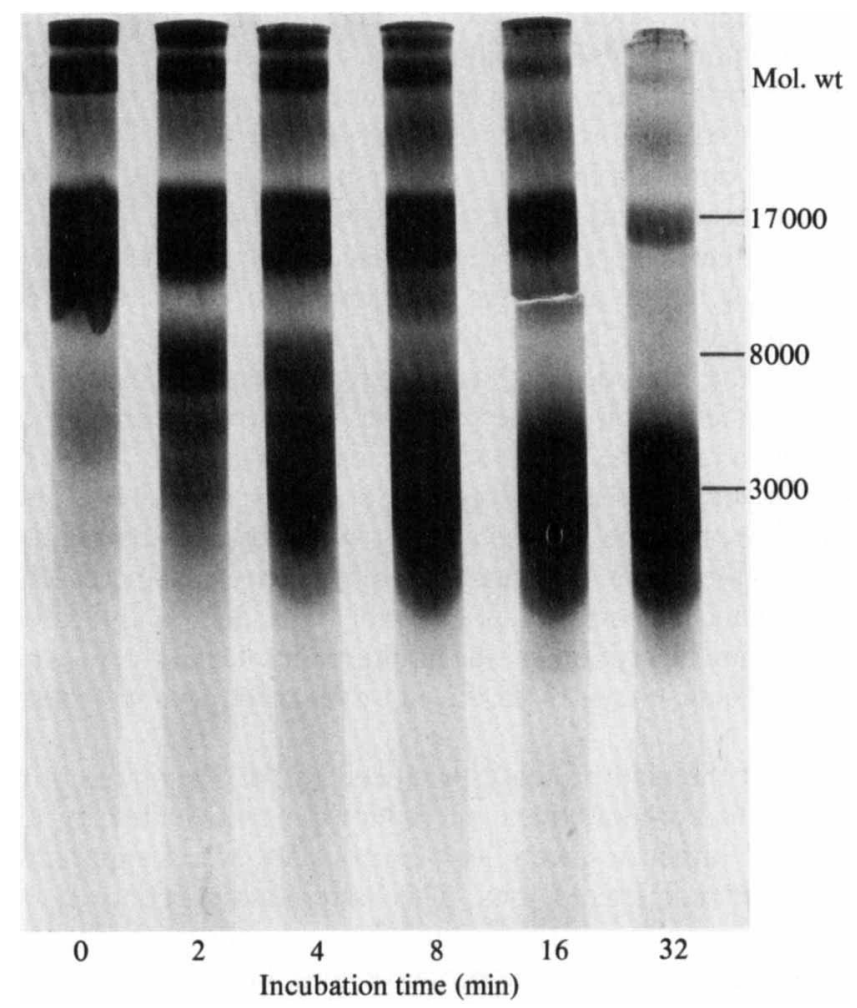

Fig. 5. Molecular weights of the TCA-soluble reaction products on SDS-polyacrylamide gels at various times of incubation with protease (as measured by the procedures illustrated in Fig. 6). The molecular weights were estimated by comparison with the migration of standard polypeptides. 


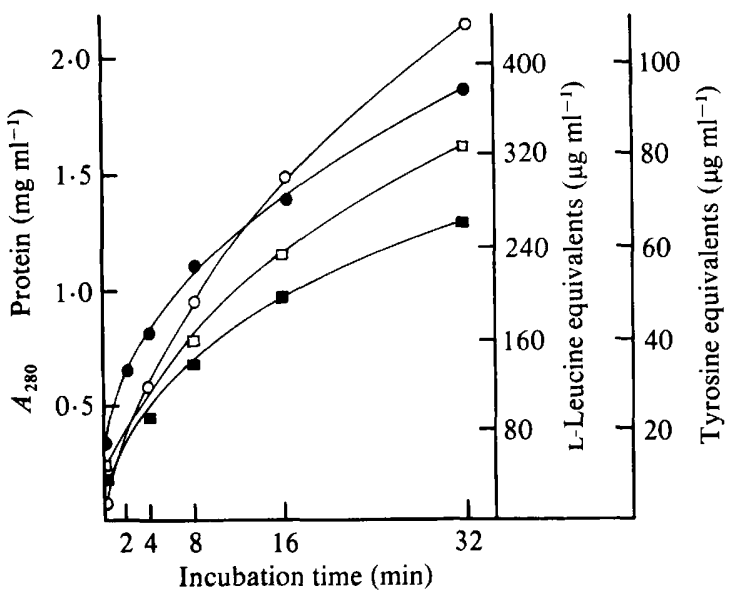

Fig. 6. Digestion of haemoglobin by the purified in vitro protease in relation to time of incubation as measured by $A_{280}(O)$, total protein (nitrogen determinations) $(\mathrm{O})$, L-leucine $(\square)$ and tyrosine $(\square)$ equivalents after precipitation by TCA.

The finding that TCA-soluble polypeptides are formed from denatured haemoglobin after only 2 min incubation with the in vitro protease (Fig. 5) suggested that the fungal acid protease might have important effects on proteins of the host cells and thereby influence pathogenicity (the $\mathrm{pH}$ of homogenized infected apple tissue is close to $3 \cdot 0$ ). This possibility was strengthened by the observed hydrolysis of the purified plant proteins vicilin and legumin. However, isolation and purification of these proteins and the acid $\mathrm{pH}$ conditions of the assay had undoubtedly contributed to their denaturation. In order to test the effect of purified acid protease produced in vitro on native proteins, inactivation of peroxidase, tyrosinase and acid phosphatase was measured. Unfortunately, all the enzymes were inactivated to some extent by incubation at the $\mathrm{pH}$ optimum for haemoglobin hydrolysis in the absence of protease so it was necessary to conduct the assays at the sub-optimal $\mathrm{pH}$ of $4 \cdot 7$. Under these conditions the enzymes remained unaffected by the acid protease. A peroxidase isoenzyme had the same electrophoretic properties before and after treatment with the protease confirming that not only had the active site been unaffected but that the molecular weight of the enzyme was also unchanged; however, the heat-denatured isoenzyme was rapidly hydrolysed. A fourth enzyme examined for inactivation by the protease was nitrate reductase since there is some evidence that this protein might be affected by proteases (Wallace, 1974), although there is no proof that inactivation is by protein hydrolysis (Sherrard et al., 1979). The results illustrated in Fig. 7(a) confirm that nitrate reductase activity was decreased by the purified protease but that activity of the cytochrome $c$ reductase component was increased (Fig. $7 b$ ). Thus, reduction of nitrate reductase activity is probably not due to hydrolysis of the enzyme proteins, but results from disruption of the multi-component system which constitutes the total enzyme complex. Pectic enzymes produced by $\boldsymbol{M}$. fructigena were also unaffected by the acid protease.

Further evidence that the acid protease produced by $M$. fructigena in vivo probably does not have a direct role in host/pathogen interactions was provided by an observation that membrane proteins of intact tobacco leaf protoplasts were apparently unaffected: the protoplasts neither lysed nor leaked ions. This latter finding contrasts with the results of Tseng \& Mount (1974) working with another fungal protease. Viable cultured apple cells failed to leak ions on treatment with the protease, and, like Ries \& Albersheim (1973) who worked with another protease secreted by a fungal pathogen, we were unable to demonstrate the release of hydroxyproline-rich proteins from walls of protease-treated cells. We were also unable to confirm the suggestion (Swinburne, 1975) that some fungal proteases are capable of 

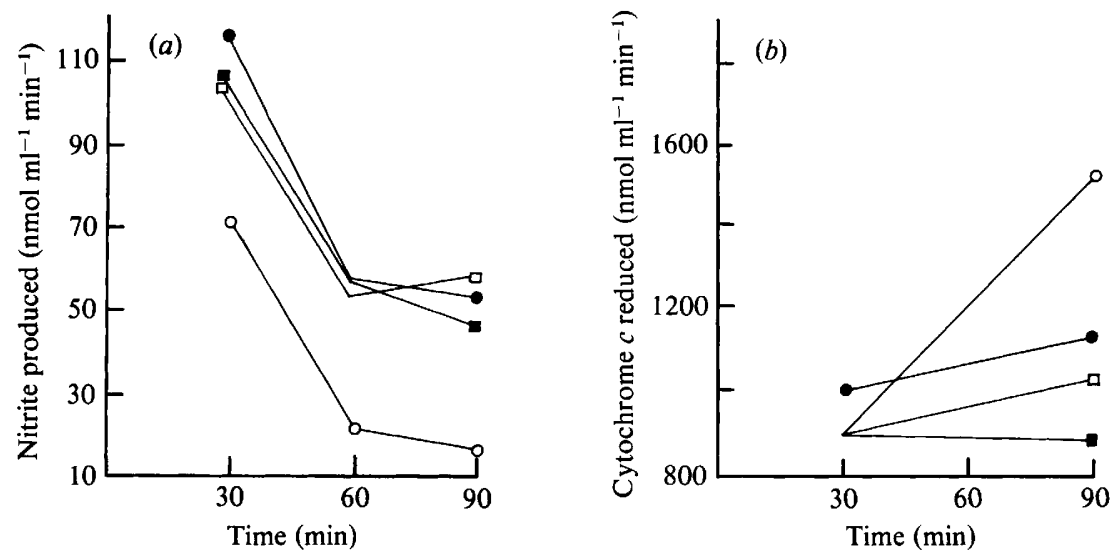

Fig. 7. Effect of purified in vitro protease on spinach nitrate reductase measured at $\mathrm{pH} 5 \cdot 0$ in terms of nitrite produced $(a)$ and cytochrome $c$ reduced $(b)$ in mixtures containing nitrate reductase alone $(\square)$, nitrate reductase + pepstatin $(\square)$, nitrate reductase + pepstatin + protease $(O)$ and nitrate reductase + protease (O).

stimulating phytoalexin production in treated plant cells, since there was no increase in such compounds when bean cotyledons were treated with $M$. fructigena protease (J. A. Hargreaves, personal communication).

Thus, we have no evidence of a direct role for the fungal protease in pathogenesis. However, the enzyme is not constitutive in vitro and it is reasonable therefore to suggest that it might have a role in the nutrition of the pathogen in vitro and possibly therefore in vivo, where infected, injured and dead tissue has a $\mathrm{pH}$ close to the optimum demonstrated in vitro and where denatured proteins are certain to occur. This possibility was strengthened by the fact that low aminopeptidase activity was detected in crude culture filtrates and extracts of infected apples, and that after partial purification the culture filtrates were shown to contain carboxypeptidase activity which in vitro had a pH optimum between 4 and 5 (J. Paver, unpublished results). If the acid protease has a role in the nutrition of the pathogen in vivo its importance in pathogenesis is obvious. However, we stress that, like most other workers, we have no information about the physiological substrates for the acid protease in vivo.

Protease secretion is readily induced in cultures of those fungal plant pathogens that have been examined, and increased amounts of protease have often been demonstrated in plant tissues infected with fungal pathogens compared with healthy plants. Our evidence and the data of Urbanek \& Yirdaw (1978) indicate that at least in some infected tissues the increased proteases are of fungal origin, although whether or not they are secreted by the pathogen in vivo or retained within the hyphae is uncertain. Any pathological roles for the fungal proteases in infected plants could be modified by natural host protease inhibitors as suggested by Ryan (1973), Mosolov et al. (1976) and Richardson (1977). Thus, recent work by Mosolov et al. (1979) demonstrating that kidney bean seeds contain a highly specific inhibitor of a protease secreted in vitro by the bean fungal pathogen Colletotrichum lindemuthianum is particularly interesting. Further, the work of Peng \& Black (1976) indicating that protease inhibitors were more abundant in tomato plants infected with an incompatible race of Phytophthora infestans compared with plants infected with a compatible race of the fungus or healthy plants suggests that interactions between proteases and inhibitors could be a factor affecting host/pathogen specificity. However, valid experiments confirming that fungal proteases interact with natural protease inhibitors in vivo thereby affecting host/pathogen interactions have yet to be performed. For example, it is not yet known if the in vitro protease examined by Mosolov et al. (1979) actually occurs in Colletotrichum lindemuthianum infected tissue, or if the protease inhibitor extracted from seeds also occurs in parts of bean 
plants commonly infected by the fungus. Also, it is not known if the inhibitors found by Peng \& Black (1976) interact with a protease produced in vivo by the fungal pathogen because only chymotrypsin and trypsin were used to assay the inhibitors. Ryan (1973), commenting on the role of protease and inhibitor interactions in plant protection, stated 'this area of research deserves much more study'. Clearly more work still remains to be done.

Dr B. A. Notton is thanked for providing data on the inactivation of spinach nitrate reductase, and $\mathrm{Mr} \mathrm{A}$. $\mathrm{H}$. Fielding for help with the isoelectric focusing.

\section{REFERENCES}

ANDREws, P. (1964). Estimation of the molecular weights of proteins by Sephadex gel-filtration. Biochemical Journal 91, 222-233.

ANson, M. L. (1938). Estimation of pepsin, trypsin, papain and cathepsin with haemoglobin. Journal of General Physiology 22, 79-89.

Aoyagi, T., Kunimoto, S., Morishima, H., TAKEUCHI, T. \& UMEZAWA, H. (1971). Effect of pepstatin on acid proteases. Journal of Antibiotics 24, 687-694.

Bateman, D. F. \& Basham, H. G. (1976). Degradation of plant cell walls and membranes by microbial enzymes. In Physiological Plant Patho$\log y$, pp. 316-355. Edited by R. Heitefuss \& P. H. Williams. Berlin: Springer Verlag.

BRADFORD, M. (1976). A rapid and sensitive method for the quantification of microgram quantities of protein utilizing the principle of protein dye-binding. Analytical Biochemistry 72, 248-254.

BYRDE, R. J. W. (1979). Role of polysaccharidedegrading enzymes in microbial pathogenicity. In Microbial Polysaccharides and Polysaccharases, pp. 417-436. Edited by R. C. W. Berkeley, G. W. Gooday \& D. C. Ellwood. London: Academic Press.

Byrde, R. J. W. \& Fielding, A. H. (1968). Pectin methyl-trans-eliminase as the maceration factor of Sclerotinia fructigena and its significance in brown rot of apple. Journal of General Microbiology 52, 287-297.

ChuA, G. K. \& Bushuk, W. (1969). Purification of wheat proteases by affinity chromatography on haemoglobin-Sepharose column. Biochemical and Biophysical Research Communications 37, 545550.

Drivdahl, R. H. \& ThimanN, K. V. (1977). Proteases of senescing oat leaves. I. Purification and general properties. Plant Physiology 59, 1059-1063.

Hislop, E. C., HoAD, G. V. \& ARCHER, S. A. (1973). The involvement of ethylene in plant diseases. In Fungal Pathogenicity and the Plant's Response, pp. 87-117. Edited by R. J. W. Byrde \& C. V. Cutting. London: Academic Press.

Hislop, E. C., KeON, J. P. R. \& Fielding, A. H. (1979). Effects of pectin lyase from Monilinia fructigena on viability, ultrastructure and localization of acid phosphatase of cultured apple cells. Physiological Plant Pathology 14, 371-381.

Huerten, S., Jerstedt, S. \& Tiselius, A. (1965). Some aspects of the use of "continuous" and "discontinuous" buffer systems in polyacrylamide gel electrophoresis. Analytical Biochemistry 11, 219-223.
KhARE, K. B. \& BompeIX, G. (1976). Activités protéolytiques des Sclerotinia sclerotiorum et $S$. minor: rôle possible de la pathogènese. Revue de mycologie 40, 65-84.

Mosolov, V. V., Loginova, M. D., Fedurkina, N. V. \& BENKEN, I. I. (1976). The biological significance of proteinase inhibitors in plants. Plant Science Letters 7, 77-80.

Mosolov, V. V., Loginova, M. D., Malova, E. L. \& BENKEN, I. I. (1979). A specific inhibitor of Colletotrichum lindemuthianum protease from kidney bean (Phaseolus vulgaris) seeds. Planta 144, 265-269.

Mussell, H. \& Strand, L. L. (1977). Pectic enzyme involvement in pathogenesis and possible relevance to tolerance and specificity. In Cell Wall Biochemistry Related to Specificity in Host-Plant Pathogen Interactions, pp. 31-70. Edited by B. Solheim \& J. Raa. Tromso: Universitets Forlaget.

Nakadi, T., Nasuno, S. \& Iguchi, N. (1972). Purification and properties of acid carboxypeptidase I from Aspergillus oryzae. Agricultural and Biological Chemistry 36, 1343-1352.

Nakadi, T., Nasuno, S. \& Iguchi, N. (1973). Purification and properties of leucine aminopeptidase I from Aspergillus oryzae. Agricultural and Biological Chemistry 37, 757-765.

PENG, J. H. \& BLACK, L. L. (1976). Increased proteinase inhibitor activity in response to infection of resistant tomato plants by Phytophthora infestans. Phytopathology 66, 958-963.

Rajagopalan, T. G., Stein, W. H. \& Moore, S. (1966). The inactivation of pepsin by diazoacetylnorleucine methyl ester. Journal of Biological Chemistry 24, 4295-4297.

Reisner, A. H., Nemes, P. \& Bucholtz, C. (1975). The use of Coomassie brilliant blue G250 perchloric acid solution for staining in electrophoresis and isoelectric focusing on polyacrylamide gels. Analytical Biochemistry 64, 509-516.

Richardson, M. (1977). The proteinase inhibitors of plants and microorganisms. Phytochemistry 16, 159-169.

Ries, S. M. \& Albersheim, P. (1973). Purification of a protease secreted by Colletotrichum lindemuthianum. Phytopathology 63, 625-629.

Rinderknecht, H., Geokas, M. C., Silverman, P. \& HAVERBACK, B. J. (1968). A new ultrasensitive method for the determination of proteolytic activity. Clinica chimica acta 21, 197-203.

Ryan, C. A. (1973). Proteolytic enzymes and their inhibitors in plants. Annual Review of Plant Physiology 24, 173-196. 
Salmia, M. A., Nyman, S. A. \& Mikola, J. J. (1978). Characterisation of the proteinase present in germinating seeds of Scots Pine, Pinus sylvestris. Physiologia plantarum 42, 252-256.

Shapiro, A. C., Vinuela, E. \& Maizel, J. V., JR (1967). Molecular weight estimation of polypeptide chains by electrophoresis in SDS-polyacrylamide gels. Biochemical and Biophysical Research Communications 28, 4295-4297.

Sherrard, J. H., Kennedy, H. A. \& Dalling, M. J. (1979). In vitro stability of nitrate reductase from wheat leaves. III. Isolation and partial characterisation of a nitrate reductase-inactivating factor. Plant Physiology 64, 640-645.

Swank, R. T. \& Munkres, K. D. (1971). Molecular weight analysis of oligopeptides by electrophoresis on polyacrylamide gel with sodium dodecyl sulphate. Analytical Biochemistry 39, 462-477.

Swinburne, T. R. (1975). Microbial proteases as elicitors of benzoic acid accumulation in apples. Phytopathologische Zeitschrift 82, 152-162.

TsaI, M. S., HseU, T. H. \& ShEN, Y. S. (1978). Purification and characterization of an acid protease from Monascus kaoliang. International Journal of Peptide and Protein Research 12, 293-302.

TSENG, T. C. \& MounT, M. S. (1974). Toxicity of endo-polygalacturonate trans-eliminase, phosphati- dase and protease to potato and cucumber tissue. Phytopathology 64, 229-236.

URbaneK, H. \& YIRDAW, G. (1978). Acid protease produced by Fusarium species in cultures and in infected seedlings. Physiological Plant Pathology 13, 81-87.

VesterberG, O. \& Svensson, H. (1966). Isoelectric fractionation, analysis and characterisation of ampholytes in natural pH gradients. Acta chemica scandinavica 20, 820-834.

Wallace, W. (1974). Purification and properties of a nitrate reductase-inactivating enzyme. Biochimica et biophysica acta 341, 265-276.

WEBER, K. \& OsBoRn, M. (1969). The reliability of molecular weight determinations by dodecyl sulphate-polyacrylamide gel electrophoresis. Journal of Biological Chemistry 244, 4406-4412.

WooD, R. K. S. (1978). Enzymes produced by fungi and bacteria. Their role in pathogenicity. Annals of Phytopathology 10, 127-135.

Yемм, E. W. \& Cocking, E. C. (1955). The determination of amino-acids with ninhydrin. Analyst 80, 209-213.

Zacharius, R. M., Zell, T. E., Morrison, J. H. \& Wooplock, J. J. (1969). Glycoprotein staining following electrophoresis on acrylamide gels. Analytical Biochemistry 30, 148-152. 